\title{
Wood and humus decay strategies by white-rot basidiomycetes correlate with two different dye decolorization and enzyme secretion patterns on agar plates
}

\author{
José M. Barrasa ${ }^{\mathrm{a}, *}$, María N. Blanco ${ }^{\mathrm{a}}$, Fernando Esteve-Raventós ${ }^{\mathrm{a}}$, Alberto Altés ${ }^{\mathrm{a}}$, \\ Julia Checa ${ }^{\mathrm{a}}$, Angel T. Martínez ${ }^{\mathrm{b}}$ and Francisco J. Ruiz-Dueñas ${ }^{\mathrm{b}}$ \\ ${ }^{a}$ Departamento de Ciencias de la Vida, Universidad de Alcalá, E-28805 Alcalá de Henares, \\ Spain \\ ${ }^{\mathrm{b} C e n t r o ~ d e ~ I n v e s t i g a c i o n e s ~ B i o l o ́ g i c a s, ~ C S I C, ~ R a m i r o ~ d e ~ M a e z t u ~ 9, ~ E-28040 ~ M a d r i d, ~ S p a i n ~}$
}

\begin{abstract}
During several forays for ligninolytic fungi in different Spanish native forests, 35 whiterot basidiomycetes growing on dead wood (16 species from 12 genera) and leaf litter (19 species from 10 genera) were selected for their ability to decolorize two recalcitrant aromatic dyes (Reactive Blue 38 and Reactive Black 5) added to malt extract agar medium. In this study, two dye decolorization patterns were observed and correlated with two ecophysiological groups (wood and humus white-rot basidiomycetes) and three taxonomical groups (orders Polyporales, Hymenochaetales and Agaricales). Depending on the above groups, different decolorization zones were observed on the dye-containing plates, being restricted to the colony area or extending to the surrounding medium, which suggested two different decay strategies. These two strategies were related to the ability to secrete peroxidases and laccases inside (white-rot wood Polyorales, Hymenochaetales and Agaricales) and outside (white-rot humus Agaricales) of the fungal colony, as revealed by enzymatic tests performed directly on the agar plates. Similar oxidoreductases production patterns were observed when fungi were grown in the absence of dyes, although the set of enzyme released was different. All these results suggest that the decolorization patterns observed could be related with the existence of two decay strategies developed by white-rot basidiomycetes adapted to wood and leaf litter decay in the field.
\end{abstract}

Keywords: Ligninolytic fungi, white-rot basidiomycetes, wood decay, leaf-litter decay, dye decolorization, enzymatic activities.

\section{Introduction}

Cellulose, hemicelluloses and lignin are the main components of plant cell walls produced by the photosynthetic activity of land plants. Lignin protects cellulose and hemicelluloses and is highly recalcitrant to degradation due to its aromatic nature and structural heterogeneity. This makes that lignocellulosic materials accumulate in forest soils, being their decomposition and recycling by saprotrophic fungi a key process in the global carbon cycle. A specialized group of basidiomycetes, the so called white-rot fungi, are the most efficient organisms degrading lignin, and constitute one of the most important ecophysiological groups of the mycobiota of soil in forest ecosystems.

Abbreviations: MnP, manganese peroxidase; LiP, lignin peroxidase; VP, versatile peroxidase; DyP, dyedecolorizing peroxidase; GP, generic peroxidase; RB38, Reactive Blue 38; RB5, Reactive Black 5; VA, veratryl alcohol; ABTS, 2,2'-azino-bis (3-ethylbenzothiazoline-6-sulphonic acid).

*Corresponding author. Phone: +34 918854943

E-mail address: josem.barrasa@uah.es (J.M. Barrasa) 
Lignocellulosic materials accumulated on forest soil are mainly represented by dead wood and leaves. According to the type of lignocellulosic material to be degraded, two types of ligninolytic basidiomycetes can be distinguished: wood and humus white-rot basidiomycetes. The former degrade wood lignin leaving a bleached substrate (Blanchette, 1995; Eriksson et al., 1990; Otjen and Blanchette, 1986) and the latter degrade lignin and polyphenols of leaves causing the so-called white-rot humus (Hintikka, 1970; Osono, 2007). Whilst white-rot wood basidiomycetes are broadly represented by members of the orders Polyporales and Hymenochaetales and some others of the order Agaricales (Worrall et al., 1997), white-rot humus basidiomycetes are mainly found among members of Agaricales (Hintikka, 1970; Osono, 2007; Steffen et al., 2002).

To degrade the complex molecule of lignin, white-rot basidiomycetes have developed an extracellular ligninolytic system, whose composition often differs between species (Floudas et al., 2012; Ruiz-Dueñas et al., 2013). In general, it is made up of low molar-mass metabolites, oxidases and ligninolytic enzymes such as laccases and especially high redox-potential peroxidases. The latter include manganese peroxidase (MnP), lignin peroxidase (LiP) and versatile peroxidase (VP) being activated by the hydrogen peroxide produced by oxidases (Martínez et al., 2005), whose genes are characteristic of white-rot fungal genomes (Floudas et al., 2012). Recently, a dyedecolorizing peroxidase (DyP) from the white-rot basidiomycete Auricularia auriculajudae has been demonstrated to oxidize a non-phenolic lignin model dimer (Liers et al., 2010). This fact, together with the higher number of DyP genes in genomes of wood white-rot fungi compared with brown-rot fungi (Floudas et al., 2012; Ruiz-Dueñas et al., 2013) suggest that this type of peroxidases may be also involved in lignin biodegradation.

Ligninolytic peroxidases and laccases have a broad substrate specificity acting directly or through mediators (Cañas and Camarero, 2010; Ruiz-Dueñas et al., 2009). The same enzymes can also degrade recalcitrant aromatic compounds (Bumpus et al., 1985; Pointing, 2001; Reddy, 1995) including synthetic aromatic dyes used in textile industries (Barrasa et al., 2009; Jarosz-Wilkolazka et al., 2002; Knapp et al., 1995; McMullan et al., 2001; Toh et al., 2003), some of which have been used to detect ligninolytic activity in culture (Gold et al., 1988). The above studies were mainly focused on wood decaying fungi, and only a few members of the group of leaf litter decomposing fungi were tested for dye decolorization (Jarosz-Wilkolazka et al., 2002). In a similar way, a fungal screening for oxidative enzymes involved in lignin degradation was carried out by Peláez et al. (1995), in which a total of 68 species belonging to different families of basidiomycetes was studied, however, a scarce number of leaf litter decomposing species was included.

In the present work, a screening of white-rot basidiomycetes growing on dead wood and leaf litter is reported by analyzing their ability to decolorize two recalcitrant aromatic dyes on agar plates, the phthalocyanine dye Reactive Blue 38 (RB38) and the azo dye Reactive Black 5 (RB5), and two decolorization patterns are described. Although fungal enzymes are generally studied in liquid media, different oxidoreductases have also been identified in agar plate cultures, being often related to the wood decay patterns caused by basidiomycetes (Käärik, 1965; Liers et al., 2011; Moukha et al., 1993; Stalpers, 1978; Westermark and Eriksson, 1974). Here, assays to detect high and low redox potential oxidoreductase activities on agar plates, with and without dyes, were carried out on representative white-rot wood and humus basidiomycetes. The decolorization patterns and enzymes produced were finally correlated with two possible strategies followed by white-rot fungi to colonize wood 
and humus. This wide screening will contribute to our knowledge of the diversity of fungi degrading lignocellulose in Spanish native forest, and their involvement in wood and leaf litter decomposition.

\section{Materials and methods}

\subsection{Fungal sampling and culture}

A total of 166 fungal strains from 123 species of basidiomycetes fruiting on dead wood and leaf litter were isolated after eight fungal forays in different Spanish native forests. The collected samples consisted of fresh fruit bodies, which were conserved at $4^{\circ} \mathrm{C}$ before grown as pure cultures. Fungal isolations were made from mycelium (5x5 mm pieces of context) aseptically removed from fruit bodies (Peláez et al., 1992) that was inoculated in Petri dishes with malt extract ( $2 \% \mathrm{wt} / \mathrm{vol})$ agar (MEA; Pronadisa) containing ampicillin (1.5 mg/L; Sigma).

Microscope examination of hyphae were performed for the presence of clamp connections confirming their basidiomycetous nature. Size and colour of the colony, shape and size of hyphae and type of septa were also checked (Stalpers, 1978). Fungal taxonomy was considered according to phylogenetic studies (Binder et al., 2005; Binder et al., 2013; Hibbett et al., 2007; Matheny et al., 2006). The type of rot was determined by the colour and characteristics of wood (Rayner and Boddy, 1988) and leaf litter (Osono, 2007) close to the fungal fruit body. Fungal dry material is deposited in AH (Herbario de la Universidad de Alcalá) and pure cultures are conserved in the fungal culture collection of Departamento de Ciencias de la Vida (Universidad de Alcalá).

\subsection{Dye decolorization assays in agar plates}

Decolorization assays were carried out on Petri dishes (9 cm diameter) with $20 \mathrm{~mL}$ of MEA containing RB38 and RB5 (both from Sigma) at two concentrations (75 and $150 \mathrm{mg} / \mathrm{L}$ ) (Fig. 1). Plugs of $0.5 \mathrm{~cm}$ diameter from MEA cultures were inoculated on plates with the synthetic dyes, which were incubated at $25^{\circ} \mathrm{C}$ and examined each two days for decolorization. The radial mycelial growth and decolourized area were measured, and only those species producing a decolorization circle of at least $2 \mathrm{~cm}$ diameter, within 15 days of incubation, were selected.

\subsection{Enzymatic assays in plates}

Enzymatic activities were tested directly on fungal colonies grown (at $25^{\circ} \mathrm{C}$ ) on: i) MEA plates; and ii) RB5 and RB38 containing MEA, where the fungi had previously decolorized these dyes, as described in section 2.2.

With this purpose, $10 \mu \mathrm{l}$ of $0.1 \mathrm{M} o$-hydroxyphenol (catechol, Merck), $o$ methoxyphenol (guaiacol, Merck), 2,6-dimethoxyphenol (syringol, Merck) or 2,2'azino-bis (3-ethylbenzothiazoline-6-sulphonic acid) (ABTS, Roche Applied Sciences) in $96 \%$ ( $\mathrm{vol} / \mathrm{vol})$ ethanol were dropped on MEA plate cultures in front of, behind or on the edge of the fungal colony. These substrates are oxidized by laccase (EC 1.10.3.2) (Baldrian, 2006), and by generic peroxidase (GP; EC 1.11.1.7), short MnP, VP and DyP (EC 1.11.1.13, 1.11.1.16 and 1.11.1.19, respectively) in the presence of hydrogen peroxide (Hofrichter et al., 2010; Morales et al., 2012). 
Ten $\mu \mathrm{l}$ of $0.1 \mathrm{M}$ RB5 or $25 \mathrm{mM}$ RB38 in 96\% (vol/vol) ethanol, which are oxidized by VP and DyP in the presence of hydrogen peroxide (Heinfling et al., 1998b; Liers et al., 2010), were assayed both on MEA plates, as previously described for phenols and ABTS, and on decolorized MEA plates. ABTS, RB5 and RB38 were not completely soluble under the above conditions and they were added as a suspension on the plate. Enzymatic oxidation of dyes mediated by 3,4-dimethoxybenzyl (veratryl) alcohol (VA, Sigma) radical resulting from VA oxidation by LiP (EC 1.11.1.14) and VP, was also examined (Tinoco et al., 2007). With this purpose, ten $\mu \mathrm{l}$ of $20 \mathrm{mM}$ VA (in $\mathrm{H}_{2} \mathrm{O}$ ) were added together with ten $\mu \mathrm{l}$ of $0.1 \mathrm{M}$ RB5 or $25 \mathrm{mM}$ RB38 prepared in $96 \%$ (vol/vol) ethanol.

Five $\mu$ l of a concentrated catalase (Sigma) solution was also supplied prior to the addition of the above substrates to remove any peroxide traces and avoid peroxidase activity. Alternatively, one $\mu \mathrm{l}$ of $10 \mathrm{mM}$ hydrogen peroxide (Merck) was simultaneously added together with dyes, ABTS or phenols to confirm the presence of peroxidases. Substrate oxidation was easily followed by changes in color.

\section{Results}

\subsection{Fungal species and their phylogenetic position}

Pure cultures of 123 species of white-rot basidiomycetes isolated from dead wood and soil litter were investigated for their ability to decolorize two recalcitrant aromatic dyes (RB38 and RB5) on MEA plates. Among them, a total of 35 species were selected because of the ability to produce a decolorization circle of at least $2 \mathrm{~cm}$ diameter within 15 days of incubation (Table 1). Polyporales and Hymenochaetales were more efficient since they decolorized both dyes at the two concentrations assayed (75 and $150 \mathrm{mg} / \mathrm{L}$ ) within 8 days, while Agaricales decolorized only RB38 at 15 days of incubation.

Brown-rot species did not decolorize the dyes and are not considered in this work. The selected species belong to three taxonomic orders - namely Polyporales, Hymenochaetales and Agaricales - and different phylogenetic clades.

\subsection{Fungal lifestyle and decay patterns}

The 35 selected species could be divided in two ecophysiological groups. The first group includes 16 species characterized by their ability to colonize and degrade dead wood in forest, mainly represented by trunks and stumps, causing a white-rot decay pattern as a consequence of lignin removal. The second group includes 19 species of leaf litter decomposing fungi, characterized by their ability to colonize and degrade dead leaves contributing to soil humus formation. The white-rot humus decay pattern also results in leaf bleaching due to polyphenol and lignin degradation. The majority of the wood decomposing species studied belongs to the order Polyporales (11) but a few of them belong to the orders Agaricales (4) and Hymenochaetales (1). Otherwise, all the humus basidiomycetes investigated (19 species) belong to the order Agaricales, most of them included in Marasmiaceae, Mycenaceae and Strophariaceae families in agreement with previous studies (Hintikka, 1988; Osono, 2007; Osono and Takeda, 2006; Tyler, 1985). The species of Agaricales degrading wood are mainly included in the Physalacriaceae family, although some members of Agaricaceae (i.e. C. striatus) and Strophariaceae (i.e. Gymnopilus junonius, synonym: G. spectabilis sensu auct.) have also developed a wood decomposing lifestyle, in agreement with Jahn (1979) (Table 1). 
Ten of the eleven white-rot Polyporales species were found on angiosperm wood. The only exception was Abortiporus biennis that, as the only species of Hymenochaetales studied (Sidera lenis), was found on coniferous wood. Among the wood-decomposing Agaricales, three species (Oudemansiella mucida, Xerula radicata and Cyathus striatus) were found on angiosperm wood and one species (G. junonius) was found on conifer wood.

\subsection{Dye plate decolorization patterns}

Two different decolorization patterns were observed when the selected fungal species were grown on MEA plates containing the two dyes assayed (Table 1 and Fig. 1). On one hand, the white-rot wood fungi were characterized by the formation of a decolorized circle inside the colony. This pattern was observed in wood Polyporales, Hymenochaetales and Agaricales. On the other hand, white-rot humus fungi exhibited a decolorization pattern characterized by the formation of a decolorized circle outside the colony. This pattern was observed in humus Agaricales.

With the only exception of Steccherinum ochraceum, which was unable to degrade RB5, all species of Polyporales, and S. lenis in Hymenochaetales, were more efficient decolorizers than Agaricales, since they degraded both dyes at the highest concentration in less than 8 days. The four species of wood Agaricales (C. striatus, G. junonius, $O$. mucida and $X$. radicata) were less efficient than the wood Polyporales and Hymenochaetales since they required more than 11 days to produce a $2 \mathrm{~cm}$ circle in RB38 plates. Among Polyporales, Phlebia radiata (Meruliaceae) was the strongest dye decolorizer since in all the cases it caused $2 \mathrm{~cm}$ decolorization at 3 days of incubation. Similar results were obtained with Coriolopsis gallica (strain AH 44705), Coriolopsis trogii, Ganoderma resinaceum and Trametes versicolor (strain AH 44710) at 4-5 days of incubation.

The two ecophysiological groups of Agaricales, namely white-rot wood and humus species, decolorized only RB38. Most of them needed 8 or more days of incubation to attain $2 \mathrm{~cm}$ decolorization in the plates with the highest dye concentration. Nevertheless, Cyathus olla (Nidulariaceae), Lycoperdon sp. (AH 44722; Agaricaceae) and Pholiota conissans (Strophariaceae) were able to produce a decolorization circle of $2 \mathrm{~cm}$ diameter in plates with RB38 in 5 days of incubation.

\subsection{In situ activity tests on different substrates added to MEA cultures}

Enzymatic assays were performed directly on MEA plates where ten species representative of the main phylogenetic clades (see Table 1) of white-rot wood Polyporales (Polyporus arcularius, Phlebia rufa, Trametes pubescens and A. biennis), white-rot wood Agaricales (X. radicata, C. striatus and G. junonius) and white-rot humus Agaricales (Mycena polygramma f. pumila, Rhodocollybia butyracea and Agrocybe pediades) under study had been previously grown. The four wood Polyporales and the three wood Agaricales were able to oxidize all the low redox potential substrates (i.e. catechol, guaiacol, syringol and ABTS) added within and on the inner edge of the fungal colony (Fig. 2 shows syringol oxidation by C. striatus) but not the two recalcitrant dyes (RB5 and RB38) even after addition of exogenous hydrogen peroxide and VA (the latter as a potential mediator). Peroxidase involvement was definitively ruled out, since the addition of catalase did not produce any significant effect on the oxidation of phenols and ABTS, and the reaction could be associated to laccase type activity. 
Similarly, the three humus Agaricales were able to oxidize the three phenols and ABTS and unable to decolorize RB5 and RB38. However, unlike that observed with the wood basidiomycetes, the oxidative activity was mainly detected on the outer edge and in front of the limits of the fungal colony (Fig. 3 shows syringol oxidation by $A$. pediades). Oxidation of ABTS and syringol was slowed down, but not completely removed, in the presence of catalase, and conversely it was accelerated when peroxide was added. According to these results, laccases would be responsible for the low activity levels observed in the presence of catalase. We could also confirm both that peroxide is generated by these fungi, and that peroxidases are produced. In addition, we could identify this activity as low redox potential generic peroxidase considering its inability to oxidize RB5 and RB38 (even in the presence of VA).

\subsection{In situ activity tests on RB5 and RB38 added to dye-MEA cultures}

Enzymatic assays were also performed by adding RB5 and RB38 on dye plates where the dyes had been previously decolorized by the fungi.

C. striatus, tested as representative of white-rot wood Agaricales, was unable to decolorize any of the dyes when added on previously decolorized RB38 plates (even after several days of subsequent incubation). The addition of the dyes was supplemented with hydrogen peroxide and VA without positive results. The above findings confirm the absence of any enzymatic activity able to oxidize these dyes, such as ligninolytic peroxidases and DyPs.

On the other hand, T. pubescens, as representative of wood Polyporales, was able to decolorize RB5 but not RB38 when added on the previously decolorized dye plates. In the RB5 plates, high decolorization activity was observed $16 \mathrm{~h}$ after RB5 addition within the colony (Fig. 4A). This ability was enhanced by hydrogen peroxide and dramatically impaired, although not completely removed, by catalase (VA did not produced any effect). These results confirm the involvement of both laccase (maybe acting through natural mediators) and peroxidase activities in the oxidation of this dye, as well as the fungal production of the hydrogen peroxide necessary for peroxidase activity. In the RB38 plates, no decolorization of RB5 was observed up to 2 days after its addition (Fig. 4B). A 6 day period was necessary when catalase was simultaneously added. Again, these results suggest the production of both hydrogen peroxide and peroxidase activity. Moreover, the long time (days) necessary to decolorize RB5 suggests de novo synthesis of the enzymes involved, unlike that observed on the RB5 plates where substrate oxidization only lasted minutes (or a few hours). Delayed decolorization by laccase and peroxidase activities was also observed with A. biennis, a second representative of wood Polyporales, although at longer incubation times (data not shown).

Finally, $R$. butyracea was tested as a representative for the white-rot humus Agaricales. This species was unable to decolorize any of the recalcitrant dyes when added alone or together with peroxide or catalase in the inner part of the colony grown on dye-containing MEA (Fig. 5A). However, both RB5 and RB38 were completely decolorized at the edge and in front of the limits of the colony when incubation was extended to $20 \mathrm{~h}$, as observed under all the experimental conditions assayed except in the presence of catalase (Fig. 5B). These results suggest de novo enzyme synthesis, as mentioned above, and confirm the importance of hydrogen peroxide in the decolorization process by this fungus. 


\section{Discussion}

\subsection{Decolorization of recalcitrant dyes by wood and humus basidiomycetes}

In the present work, we describe for the first time two different decolorization patterns by white-rot basidiomycetes based on results of 35 fungal species grown on dye-containing MEA plates. White-rot basidiomycetes can be classified as either wood or leaf litter decomposers. However a few species have been reported to decompose both wood and leaf litter, such as Hypholoma species (Snajdr et al., 2010; Steffen, 2003). Moreover, species growing on partially decayed and buried wood (e.g. Agrocybe aegerita) cause a nonspecific type of rot (Dix and Webster, 1995). Therefore, further studies on the latter ecophysiological groups of fungi should be carried out for dye decolorization patterns and enzymatic activities. Interestingly, different lignin degradation and oxidoreductases secretion patterns were found, respectively, between white-rot wood, white-rot leaf litter and nonspecific wood rot basidiomycetes, growing on lignocellulosic materials (Liers et al., 2011).

A screening of 30 wood-rotting basidiomycetes of different taxonomic groups for both decolorization of RB5 and RB38 and ligninolytic activities was carried out by Barrasa et al. (2009) and only two white-rot wood Polyporales and one Dacrymycetal were reported to decolorize both dyes within 5 incubation days. Moreover, no white-rot humus basidiomycetes were included in this study and, therefore, differential decolorization patterns could not be established. On the other hand, Jarosz-Wilkolazka et al. (2002) compared dye decolorization by 115 fungal strains, but only one white-rot humus species of Agaricales and 12 wood-rotting species (8 Polyporales and 4 Agaricales) were reported to decolorize the azo dye assayed (Acid Red 183). In the present work, none of the white-rot humus species of Agaricales assayed were able to decolorize the azo dye (RB5), but 15 white-rot wood species (14 Polyporales and 1 Hymenochaetal) were able to decolorize this dye within 8 incubation days. This suggest that the azo dye is more recalcitrant to fungal degradation, and that white-rot wood Polyporales and Hymenochaetales shows higher ability to decolorize it. However, after grown on RB38 plates, some white-rot humus Agaricales (i.e. $R$. butyracea) seem to be prepared to decolorize more recalcitrant dyes, such as RB5, by a mechanism that should be more in depth investigated.

\subsection{Ecophysiological groups and dye-decolorizing enzymes in white-rot basidiomycetes}

This is also the first time that a correlation between ecophysiological groups of lignin degrading basidiomycetes and dye decolorization patterns is observed. Dye decolorization is a simple assay for the identification of fungal ability to transform lignin. Both lignin and the recalcitrant dyes assayed are aromatic compounds that can be oxidized by ligninolytic peroxidases in the presence of hydrogen peroxide (Heinfling et al., 1998a; Ollikka et al., 1993; Tinoco et al., 2007). This reaction has been described to be catalyzed directly or in the presence of low molecular mass compounds acting as mediators (Ruiz-Dueñas and Martínez, 2009). Among them, VA was the first aromatic compound described as a natural mediator in cultures of the model white-rot fungus Phanerochaete chrysosporium (Harvey et al., 1986), and it is this compound which was used here to try to identify high-redox potential peroxidases that are not able to directly oxidize RB5 and RB38. DyPs were the second superfamily of high-redox potential 
peroxidases recently described as able to directly oxidize both recalcitrant aromatic dyes and lignin model compounds (Liers et al., 2010; Liers et al., 2013). Finally, laccases have been also described as able to oxidize lignin model compounds and dyes especially in the presence of mediators, including those synthesized by white-rot fungi (Cañas and Camarero, 2010). In consequence, it was expected that these extracellular enzymes should be produced in MEA plates during the decolorization of RB5 and RB38 by the white-rot basidiomycetes studied, as previously reported for several white-rot fungi growing in the presence of dyes (Casas et al., 2007; Eichlerova et al., 2005; Eichlerova et al., 2006b; Eichlerova et al., 2006a; Mendonca et al., 2008; Rodríguez-Couto, 2012; Salame et al., 2012).

The enzymatic assays performed in three regions of the fungal plates - within, on the edge, and outside the limits of the fungal colony - revealed that indeed laccases and peroxidases are released in those regions where dyes are decolorized in cultures of white-rot wood Agaricales and Polyporales (within and on the inner edge of the colony) and white-rot humus Agaricales (on the outer edge and outside the limits of the colony). The C. striatus plates where RB5 and RB38 had been previously decolorized provided the only exception, since no enzymatic activities could be detected, most probably due to enzyme inactivation after dye decolorization. This could be due to the action of proteases, which were reported to inactivate ligninolytic peroxidases in fungal cultures (Cabaleiro et al., 2002) and also cause laccase inactivation (Palmieri et al., 2000).

On the other hand, the enzymatic analysis on MEA plates without dyes revealed basically the same wood and humus basidiomycete secretion patterns identified on the dye plates, although the set of secreted enzymes was not competent for dye decolorization. The latter is easily understandable considering that genes encoding the wide range of peroxidases and laccases secreted by white-rot fungi are differentially regulated in response to a variety of environmental signals, including nitrogen and carbon sources, xenobiotics and oxidative stress, among others (Janusz et al., 2013).

\subsection{Decay strategies by white-rot wood and humus basidiomycetes}

All the above results together suggest two different strategies used by wood and humus white-rot basidiomycetes to colonize and degrade their respective substrates. These strategies would be related to the ability of different regions of the fungal colony to release oxidative enzymes acting on aromatic compounds, including the recalcitrant dyes used in the present study and the lignin polymer in nature (Martínez et al., 2005; Osono, 2007). It was shown that these strategies involve different patterns of oxidoreductase secretion by the fungi assayed that, according to our results, are basically independent on the presence or absence of aromatic compounds (dyes). However, the composition of the culture medium seems to determine the specific enzymes secreted, as demonstrated for the production of peroxidases and laccases able to decolorize dyes that were only detectable when these compounds were present.

It is observed that white-rot wood basidiomycetes release their oxidative enzymes in the area initially colonized by the fungal mycelium. Such behavior has been described for the white-rot wood fungus $P$. chrysosporium growing on dye plates (Moukha et al., 1993), where ligninolytic peroxidases are secreted by secondary hyphae produced in the center of the colony coinciding with the dye decolorization area. We suggest that the decolorization pattern produced by white-rot wood basidiomycetes on agar plates (Figs. $1 \mathrm{~B}, \mathrm{C}, \mathrm{E}$ ) would be related to their strategy for substrate colonization and degradation in nature. Wood constitutes a hardly-colonized substrate where fungal colonies have physical and nutritional limitations to growth and extend their action. In this context, the 
production of ligninolytic enzymes seems to be more active in secondary hyphae located at the center of the colony, with a limited diffusion to the outer region and the surrounding medium (Figs. 2 and 4).

On the contrary, white-rot humus basidiomycetes efficiently secrete peroxidases and laccases from young hyphae located at the periphery of the colony (Figs 1G, 3 and 5B). It has been observed that the secreted oxidoreductases subsequently diffuse in the medium acting on the synthetic dyes in the same way as they would act on leaf litter lignin in nature, allowing the fungi to colonize the soil. Thus, the decolorization pattern observed in white-rot humus basidiomycetes - i.e. outside of the limit of colony - would be related to the nature of the decayed substrate. At the contrary of wood, in this case the substrate is constituted by a whole of unrestricted elements (intermixed dead leaves), and all of this entire system provides a habitat for fungal colonization. Under these conditions, the ligninolytic system would be more active in environment exploring by young hyphae, and could involve the secretion and diffusion of ligninolytic enzymes for degradation of lignin and other aromatic compounds in dead leaves.

\section{Conclusions}

The differential dye decolorization and enzyme expression/secretion patterns observed suggest that differences in lignocellulose composition and structure could play an important role in wood and humus white-rot (ligninolytic) basidiomycetes diversity. This would include divergent strategies to colonize and degrade wood and leaf-litter by white-rot basidiomycetes, under natural conditions. Such strategies would be related to the metabolic state of the active mycelium, the production of ligninolytic oxidoreductases and their eventual diffusion in the environment, as suggested by the different dye decolorization and enzyme secretion patterns observed in plate cultures of wood and humus fungi. This hypothesis should be corroborated by laboratory studies using more natural (sawdust and leaf litter) growth media. In addition, further investigations aimed to determine the factors regulating oxidoreductase expression and diffusion (or immobilization) are required to explain the differences observed between the two ecophysiological groups of fungi here studied.

\section{Acknowledgments}

This work was supported by the CGL2009-07316 (to JMB) and BIO2011-26694 (to FJR-D) projects of the Spanish Ministry of Economy and Competitiveness (MINECO), and by the PEROXICATS (KBBE-2010-4-265397) and INDOX (KBBE-2013.3.3-04613549 of the European Union (to ATM). FJR-D thanks a "Ramón y Cajal" contract of the Spanish MINECO.

\section{References}

Baldrian, P., 2006. Fungal laccases - occurrence and properties. FEMS Microbiol. Rev. 30, 215242.

Barrasa, J.M., Martínez, A.T., Martínez, M.J., 2009. Isolation and selection of novel basidiomycetes for decolorization of recalcitrant dyes. Folia Microbiol. Prague 54, 59-66.

Binder, M., Hibbett, D.S., Larsson, K.H., Larsson, E., Langer, E., Langer, G., 2005. The phylogenetic distribution of resupinate forms across the major clades of mushroom-forming fungi (Homobasidiomycetes). Syst. Biodivers. 3, 113-157. 
Binder, M., Justo, A., Riley, R., Salamov, A., Lopez-Giraldez, F., Sjokvist, E., Copeland, A., Foster, B., Sun, H., Larsson, E., Larsson, K.H., Townsend, J., Grigoriev, I.V., Hibbett, D.S., 2013. Phylogenetic and phylogenomic overview of the Polyporales. Mycologia 105, 1350-1373.

Blanchette, R.A., 1995. Degradation of the lignocellulose complex in wood. Can. J. Bot. 73, S999S1010.

Bumpus, J.A., Tien, M., Wright, D., Aust, S.D., 1985. Oxidation of persistent environmental pollutants by a white rot fungus. Science 228, 1434-1436.

Cabaleiro, D.R., Rodríguez-Couto, S., Sanromán, M.A., Longo, M.A., 2002. Comparison between the protease production ability of ligninolytic fungi cultivated in solid state media. Process Biochem. 37, 1017-1023.

Cañas, A.I., Camarero, S., 2010. Laccases and their natural mediators: Biotechnological tools for sustainable eco-friendly processes. Biotechnol. Adv. 28, 694-705.

Casas, N., Blanquez, P., Gabarrell, X., Vicent, T., Caminal, G., Sarra, M., 2007. Degradation of orange $\mathrm{G}$ by laccase: Fungal versus enzymatic process. Environ. Technol. 28, 1103-1110.

Dix, N.J., Webster, J., 1995. Fungal ecology. Chapman and Hall, London.

Eichlerova, I., Homolka, L., Lisa, L., Nerud, F., 2005. Orange G and Remazol Brilliant Blue R decolorization by white rot fungi Dichomitus squalens, Ischnoderma resinosum and Pleurotus calyptratus. Chemosphere 60, 398-404.

Eichlerova, I., Homolka, L., Lisa, L., Nerud, F., 2006a. The influence of extracellular H2O2 production on decolorization ability in fungi. J. Basic Microb. 46, 449-455.

Eichlerova, I., Homolka, L., Nerud, F., 2006b. Ability of industrial dyes decolorization and ligninolytic enzymes production by different Pleurotus species with special attention on Pleurotus calyptratus, strain CCBAS 461. Process Biochem. 41, 941-946.

Eriksson, K.-E.L., Blanchette, R.A., Ander, P., 1990. Microbial and enzymatic degradation of wood components. Springer-Verlag, Berlin.

Floudas, D., Binder, M., Riley, R., Barry, K., Blanchette, R.A., Henrissat, B., Martínez, A.T., Otillar, R., Spatafora, J.W., Yadav, J.S., Aerts, A., Benoit, I., Boyd, A., Carlson, A., Copeland, A., Coutinho, P.M., de Vries, R.P., Ferreira, P., Findley, K., Foster, B., Gaskell, J., Glotzer, D., Górecki, P., Heitman, J., Hesse, C., Hori, C., Igarashi, K., Jurgens, J.A., Kallen, N., Kersten, P., Kohler, A., Kües, U., Kumar, T.K.A., Kuo, A., LaButti, K., Larrondo, L.F., Lindquist, E., Ling, A., Lombard, V., Lucas, S., Lundell, T., Martin, R., McLaughlin, D.J., Morgenstern, I., Morin, E., Murat, C., Nolan, M., Ohm, R.A., Patyshakuliyeva, A., Rokas, A., Ruiz-Dueñas, F.J., Sabat, G., Salamov, A., Samejima, M., Schmutz, J., Slot, J.C., St.John, F., Stenlid, J., Sun, H., Sun, S., Syed, K., Tsang, A., Wiebenga, A., Young, D., Pisabarro, A., Eastwood, D.C., Martin, F., Cullen, D., Grigoriev, I.V., Hibbett, D.S., 2012. The Paleozoic origin of enzymatic lignin decomposition reconstructed from 31 fungal genomes. Science 336, 1715-1719.

Gold, M.H., Glenn, J.K., Alic, M., 1988. Use of polymeric dyes in lignin biodegradation assays. Methods Enzymol. 161, 74-78.

Harvey, P.J., Schoemaker, H.E., Palmer, J.M., 1986. Veratryl alcohol as a mediator and the role of radical cations in lignin biodegradation by Phanerochaete chrysosporium. FEBS Lett. 195, 242246.

Heinfling, A., Martínez, M.J., Martínez, A.T., Bergbauer, M., Szewzyk, U., 1998a. Transformation of industrial dyes by manganese peroxidase from Bjerkandera adusta and Pleurotus eryngii in a manganese-independent reaction. Appl. Environ. Microbiol. 64, 2788-2793.

Heinfling, A., Ruiz-Dueñas, F.J., Martínez, M.J., Bergbauer, M., Szewzyk, U., Martínez, A.T., 1998b. A study on reducing substrates of manganese-oxidizing peroxidases from Pleurotus eryngii and Bjerkandera adusta. FEBS Lett. 428, 141-146.

Hibbett, D.S., Binder, M., Bischoff, J.F., Blackwell, M., Cannon, P.F., Eriksson, O.E., Huhndorf, S., James, T., Kirk, P.M., Lucking, R., Lumbsch, H.T., Lutzoni, F., Matheny, P.B., McLaughlin, D.J., Powell, M.J., Redhead, S., Schoch, C.L., Spatafora, J.W., Stalpers, J.A., Vilgalys, R., Aime, M.C., Aptroot, A., Bauer, R., Begerow, D., Benny, G.L., Castlebury, L.A., Crous, P.W., Dai, Y.C., Gams, W., Geiser, D.M., Griffith, G.W., Gueidan, C., Hawksworth, D.L., Hestmark, G., Hosaka, K., Humber, R.A., Hyde, K.D., Ironside, J.E., Koljalg, U., Kurtzman, C.P., Larsson, K.H., Lichtwardt, R., Longcore, J., Miadlikowska, J., Miller, A., Moncalvo, J.M., MozleyStandridge, S., Oberwinkler, F., Parmasto, E., Reeb, V., Rogers, J.D., Roux, C., Ryvarden, L., 
Sampaio, J.P., Schussler, A., Sugiyama, J., Thorn, R.G., Tibell, L., Untereiner, W.A., Walker, C., Wang, Z., Weir, A., Weiss, M., White, M.M., Winka, K., Yao, Y.J., Zhang, N., 2007. A higher-level phylogenetic classification of the Fungi. Mycol. Res. 111, 509-547.

Hintikka, V., 1970. Studies on white-rot humus former by higher fungi forest soils. Commun. Inst. For. Fenn. 69, 1-68.

Hintikka, V., 1988. On the macromycete flora in the oligotrophic pine forests of different ages in south Finland. Acta Bot. Fenn. 136, 89-94.

Hofrichter, M., Ullrich, R., Pecyna, M.J., Liers, C., Lundell, T., 2010. New and classic families of secreted fungal heme peroxidases. Appl. Microbiol. Biotechnol. 87, 871-897.

Jahn, H., 1979. Pilze, die an Holz wachsen. Busse Seewald Verlag, Herford.

Janusz, G., Kucharzyk, K.H., Pawlik, A., Staszczak, M., Paszczynski, A.J., 2013. Fungal laccase, manganese peroxidase and lignin peroxidase: Gene expression and regulation. Enzyme Microb. Technol. 52, 1-12.

Jarosz-Wilkolazka, A., Kochmanska-Rdest, J., Malarczyk, E., Wardas, W., Leonowicz, A., 2002. Fungi and their ability to decolourize azo and anthraquinonic dyes. Enzyme Microb. Technol. 30, 566-572.

Käärik, A., 1965. The identification of the mycelia of wood-decay fungi by their oxidation reactions with phenolic compounds. Stud. For. Suec. 31, 3-81.

Knapp, J.S., Newby, P.S., Reece, L.P., 1995. Decolorization of dyes by wood-rotting basidiomycete fungi. Enzyme Microb. Technol. 17, 664-668.

Liers, C., Arnstadt, T., Ullrich, R., Hofrichter, M., 2011. Patterns of lignin degradation and oxidative enzyme secretion by different wood- and litter-colonizing basidiomycetes and ascomycetes grown on beech-wood. FEMS Microbiol. Ecol. 78, 91-102.

Liers, C., Bobeth, C., Pecyna, M., Ullrich, R., Hofrichter, M., 2010. DyP-like peroxidases of the jelly fungus Auricularia auricula-judae oxidize nonphenolic lignin model compounds and highredox potential dyes. Appl. Microbiol. Biotechnol. 85, 1869-1879.

Liers, C., Pecyna, M.J., Kellner, H., Worrich, A., Zorn, H., Steffen, K.T., Hofrichter, M., Ullrich, R., 2013. Substrate oxidation by dye-decolorizing peroxidases (DyPs) from wood-and litterdegrading agaricomycetes compared to other fungal and plant heme-peroxidases. Appl. Microbiol. Biotechnol. 97, 5839-5849.

Martínez, A.T., Speranza, M., Ruiz-Dueñas, F.J., Ferreira, P., Camarero, S., Guillén, F., Martínez, M.J., Gutiérrez, A., del Río, J.C., 2005. Biodegradation of lignocellulosics: Microbiological, chemical and enzymatic aspects of fungal attack to lignin. Int. Microbiol. 8, 195-204.

Matheny, P.B., Curtis, J.M., Hofstetter, V., Aime, M.C., Moncalvo, J.M., Ge, Z.W., Yang, Z.L., Slot, J.C., Ammirati, J.F., Baroni, T.J., Bougher, N.L., Hughes, K.W., Lodge, D.J., Kerrigan, R.W., Seidl, M.T., Aanen, D.K., DeNitis, M., Daniele, G.M., Desjardin, D.E., Kropp, B.R., Norvell, L.L., Parker, A., Vellinga, E.C., Vilgalys, R., Hibbett, D.S., 2006. Major clades of Agaricales: a multilocus phylogenetic overview. Mycologia 98, 982-995.

McMullan, G., Meehan, C., Conneely, A., Kirby, N., Robinson, T., Nigam, P., Banat, I.M., Marchant, R., Smyth, W.E., 2001. Microbial decolourisation and degradation of textile dyes. Appl. Microbiol. Biotechnol. 56, 81-87.

Mendonca, R.T., Jara, J.F., Gonzalez, V., Elissetche, J.P., Freer, J., 2008. Evaluation of the whiterot fungi Ganoderma australe and Ceriporiopsis subvermispora in biotechnological applications. J. Ind. Microbiol. Biotechnol. 35, 1323-1330.

Morales, M., Mate, M.J., Romero, A., Martínez, M.J., Martínez, A.T., Ruiz-Dueñas, F.J., 2012. Two oxidation sites for low redox-potential substrates: A directed mutagenesis, kinetic and crystallographic study on Pleurotus eryngii versatile peroxidase. J. Biol. Chem. 287, 4105341067.

Moukha, S.M., Wösten, H.A.B., Asther, M., Wessels, J.G.H., 1993. In situ localization of the secretion of lignin peroxidases in colonies of Phanerochaete chrysosporium using a sandwiched mode of culture. J. Gen. Microbiol. 139, 969-978.

Ollikka, P., Alhonmaki, K., Leppanen, V.M., Glumoff, T., Raijola, T., Suominen, I., 1993. Decolorization of azo, triphenyl methane, heterocyclic, and polymeric dyes by lignin peroxidase isoenzymes from Phanerochaete chrysosporium. Appl. Environ. Microbiol. 59, 4010-4016. 
Osono, T., 2007. Ecology of ligninolytic fungi associated with leaf litter decomposition. Ecological Research 22, 955-974.

Osono, T., Takeda, H., 2006. Fungal decomposition of Abies needle and Betula leaf litter. Mycologia 98, 172-179.

Otjen, L., Blanchette, R.A., 1986. A discussion of microstructural changes in wood during decomposition by white rot basidiomycetes. Can. J. Bot. 64, 905-911.

Palmieri, G., Giardina, P., Bianco, C., Fontanella, B., Sannia, G., 2000. Copper induction of laccase isoenzymes in the ligninolytic fungus Pleurotus ostreatus. Appl. Environ. Microbiol. 66, 920-924.

Peláez, F., Diez, M.T., Calonge, F.D., 1992. Obtención de cultivos puros de Basidiomycotina a partir de carpóforos recogidos en España. Bol. Soc. Micol. Madrid 17, 153-165.

Peláez, F., Martínez, M.J., Martínez, A.T., 1995. Screening of 68 species of basidiomycetes for enzymes involved in lignin degradation. Mycol. Res. 99, 37-42.

Pointing, S.B., 2001. Feasibility of bioremediation by white-rot fungi. Appl. Microbiol. Biotechnol. 57, 20-33.

Rayner, A.D.M., Boddy, L., 1988. Fungal decomposition of wood: Its biology and ecology. A Wiley-Interscience Publication, Chichester.

Reddy, C.A., 1995. The potential for white-rot fungi in the treatment of pollutants. Curr. Opin. Biotechnol. 6, 320-328.

Rodríguez-Couto, S., 2012. A promising inert support for laccase production and decolouration of textile wastewater by the white-rot fungus Trametes pubescesns. J. Hazard. Mater. 233, 158162.

Ruiz-Dueñas, F.J., Lundell, T., Floudas, D., Nagy, L.G., Barrasa, J.M., Hibbett, D.S., Martínez, A.T., 2013. Lignin-degrading peroxidases in Polyporales: An evolutionary survey based on ten sequenced genomes. Mycologia doi:10.3852/13-059.

Ruiz-Dueñas, F.J., Martínez, A.T., 2009. Microbial degradation of lignin: How a bulky recalcitrant polymer is efficiently recycled in nature and how we can take advantage of this. Microbial Biotechnol. 2, 164-177.

Ruiz-Dueñas, F.J., Morales, M., García, E., Miki, Y., Martínez, M.J., Martínez, A.T., 2009. Substrate oxidation sites in versatile peroxidase and other basidiomycete peroxidases. J. Exp. Bot. 60, 441-452.

Salame, T.M., Knop, D., Levinson, D., Mabjeesh, S.J., Yarden, O., Hadar, Y., 2012. Release of Pleurotus ostreatus Versatile-Peroxidase from Mn2+ Repression Enhances Anthropogenic and Natural Substrate Degradation. PLoS One 7.

Snajdr, J., Steffen, K.T., Hofrichter, M., Baldrian, P., 2010. Transformation of (14)C-labelled lignin and humic substances in forest soil by the saprobic basidiomycetes Gymnopus erythropus and Hypholoma fasciculare. Soil Biol. Biochem. 42, 1541-1548.

Stalpers, J.A., 1978. Identification of wood-inhabiting Aphyllophorales in pure culture. Stud. Mycol. 16, 1-48.

Steffen, K.T., 2003. Degradation of recalcitrant biopolymers and polycyclic aromatic hydrocarbons by litter-decomposing basidiomycetous fungi. University of Helsinki, Ph D thesis.

Steffen, K.T., Hatakka, A., Hofrichter, M., 2002. Degradation of humic acids by the litterdecomposing basidiomycete Collybia dryophila. Appl. Environ. Microbiol. 68, 3442-3448.

Tinoco, R., Verdín, J., Vázquez-Duhalt, R., 2007. Role of oxidizing mediators and tryptophan 172 in the decoloration of industrial dyes by the versatile peroxidase from Bjerkandera adusta. J. Mol. Catal. B-Enzym. 46, 1-7.

Toh, Y.C., Yen, J.J.L., Obbard, J.P., Ting, Y.P., 2003. Decolourisation of azo dyes by white-rot fungi (WRF) isolated in Singapore. Enzyme Microb. Technol. 33, 569-575.

Tyler, G., 1985. Macrofungal flora of Swedish beech forest related to soil organic-matter and acidity characteristics. Forest Ecol. Manag. 10, 13-29.

Westermark, U., Eriksson, K.E., 1974. Carbohydrate-dependent enzymic quinone reduction during lignin degradation. Acta Chem. Scand. B 28, 204-208.

Worrall, J.J., Anagnost, S.E., Zabel, R.A., 1997. Comparison of wood decay among diverse lignicolous fungi. Mycologia 89, 199-219. 
Fig. 1. Agar-plate dye $(150 \mathrm{mg} / \mathrm{ml})$ decolorization patterns. A-C. Polyporus arcularius (AH 44709): A. Basidiocarp. B,C. Dye decolorization inside the fungal colony (white-rot wood decolorization pattern): B. Culture in MEA + Reactive Black 5. C. Culture in MEA + Reactive Blue 38. D,E. Cyathus striatus (AH 40144): D. Basidiocarps. E. Dye decolorization inside the fungal colony (white-rot wood decolorization pattern), culture in MEA + Reactive Blue 38. F,G. Rhodocollybia butyracea (AH 40177): F. Basidiocarps. G. Dye decolorization outside the fungal colony (white-rot humus decolorization pattern), culture in MEA + Reactive Blue 38. Black arrows $=$ edge of fungal colonies. White arrows $=$ decolorization areas. Bars $=10 \mathrm{~mm}$.

Fig. 2. Syringol (S) oxidation catalyzed by Cyathus striatus (AH 40144) (white-rot wood basidiomycete) grown on MEA plate. Syringol was added alone (S) and in the presence of hydrogen peroxide $\left(\mathrm{S}+\mathrm{H}_{2} \mathrm{O}_{2}\right)$ or catalase ( $\mathrm{S}+$ catalase). The three reactions were initiated at the same time, both within and on the edge of the fungal colony.

Fig. 3. Syringol (S) oxidation catalyzed by Agrocybe pediades (AH 40210) (white-rot humus basidiomycete) grown on MEA plate. Syringol was added alone (S) and in the presence of hydrogen peroxide $\left(\mathrm{S}+\mathrm{H}_{2} \mathrm{O}_{2}\right.$ ) or catalase ( $\mathrm{S}+$ catalase). The above three reactions were initiated at the same time and were tested in a single plate, first in front of (A) and then within (B) the limits of the fungal colony, in the following order: i) $\boldsymbol{a} 1$ and then $\boldsymbol{a} \mathbf{2}$ (in front of the edge of the colony); and ii) $\boldsymbol{b}$ (within the colony). $\boldsymbol{a} 2$ reactions were initiated with a $10 \mathrm{~min}$ delay with respect to the $\boldsymbol{a 1}$ onset and both were developed 5 min later. Syringol oxidation in $\boldsymbol{a} \mathbf{1}$ and $\boldsymbol{a} 2$ was faster in the presence of hydrogen peroxide and slower in the presence of catalase. The $\boldsymbol{a} \mathbf{1}$ and $\boldsymbol{a} \mathbf{2}$ reactions are saturated in $\mathbf{B}$.

Fig. 4. Reactive Black 5 (RB5) and Reactive Blue 38 (RB38) oxidation assays in MEA plates where Trametes pubescens (AH 44704) (white-rot wood basidiomycete) has previously decolorized these two dyes (RB5 in A and RB38 in B). Both dyes were added alone or together with catalase, hydrogen peroxide, veratryl alcohol (VA) or VA plus hydrogen peroxide, as described in Materials and Methods. RB38 was not oxidized under any of the conditions tested and RB5 oxidation was evidenced by formation of a reddish-brown product after 16 and 48 hours incubation in plates $\mathbf{A}$ and $\mathbf{B}$ respectively.

Fig. 5. Reactive Black 5 (RB5) and Reactive Blue 38 (RB38) oxidation assays in MEA plate where RB38 has been previously decolorized by Rhodocollybia butyracea (AH 40177) (whiterot humus basidiomycete). A. Both dyes (still not oxidized) immediately after added alone or together with catalase, hydrogen peroxide, veratryl alcohol (VA) or VA plus hydrogen peroxide on the previously decolorized area (inside, red labels, and on the edge, black labels, of the fungal colony). B. Both dyes completely decolorized (on the edge of the colony) after $20 \mathrm{~h}$ incubation under all the experimental conditions tested, except when catalase was simultaneously added. Neither of the two dyes was decolorized behind the limits of the colony. 
Table 1.- Selected species decolorizing agar-plates dyes (decolorization ring $=2 \mathrm{~cm}$. diameter) during 15 days of incubation.

\begin{tabular}{|c|c|c|c|c|c|c|c|c|c|c|}
\hline \multirow{2}{*}{$\mathbf{N}^{\circ} \mathbf{A H}$} & \multirow{2}{*}{ Species } & \multirow{2}{*}{ Family } & \multirow{2}{*}{ Order } & \multirow{2}{*}{$\begin{array}{l}\text { Phylogenetic } \\
\text { position }\end{array}$} & \multirow{2}{*}{ Substrate, Location } & \multirow{2}{*}{ RB38 } & \multirow{2}{*}{ RB5 } & \multicolumn{2}{|c|}{$\begin{array}{l}\text { Days required for } \\
\text { decolorization }\end{array}$} & \multirow{2}{*}{$\begin{array}{c}\text { Decolori } \\
\text {-zation } \\
\text { pattern }\end{array}$} \\
\hline & & & & & & & & RB38 & RB5 & \\
\hline 44723 & $\begin{array}{l}\text { Abortiporus biennis (Bull.) } \\
\text { Singer }\end{array}$ & Meruliaceae & Polyporales & $\begin{array}{c}\text { residual } \\
\text { polyporoid clade }\end{array}$ & $\begin{array}{l}\text { Wood (Pinus radiata), Pared Vieja } \\
\text { (La Palma) }\end{array}$ & + & + & 8 & 8 & WRW \\
\hline 44705 & $\begin{array}{l}\text { Coriolopsis gallica (Fr.) } \\
\text { Ryvarden } \\
\end{array}$ & Polyporaceae & Polyporales & $\begin{array}{l}\text { core polyporoid } \\
\text { clade }\end{array}$ & $\begin{array}{c}\text { Wood (Acer platanoides), Pedrezuela } \\
\text { (Madrid) }\end{array}$ & + & + & 4 & 4 & WRW \\
\hline 44712 & $\begin{array}{l}\text { Coriolopsis gallica }(\mathrm{Fr} .) \\
\text { Ryvarden }\end{array}$ & Polyporaceae & Polyporales & $\begin{array}{l}\text { core polyporoid } \\
\text { clade }\end{array}$ & $\begin{array}{l}\text { Wood (Ocotea foetens), Cubo de la } \\
\text { Galga (La Palma) }\end{array}$ & + & + & 6 & 6 & WRW \\
\hline 44706 & $\begin{array}{l}\text { Coriolopsis trogii (Berk.) } \\
\text { Domański }\end{array}$ & Polyporaceae & Polyporales & $\begin{array}{l}\text { core polyporoid } \\
\text { clade }\end{array}$ & $\begin{array}{c}\text { Wood (Populus alba), Alcalá de } \\
\text { Henares (Madrid) }\end{array}$ & + & + & 5 & 5 & WRW \\
\hline 44707 & $\begin{array}{c}\text { Ganoderma resinaceum } \\
\text { Boud. }\end{array}$ & Ganodermataceae & Polyporales & $\begin{array}{l}\text { core polyporoid } \\
\text { clade }\end{array}$ & $\begin{array}{l}\text { Wood (Ligustrum lucidum), Alcalá de } \\
\text { Henares (Madrid) }\end{array}$ & + & + & 5 & 5 & WRW \\
\hline 44713 & Ganoderma australe (Fr.) Pat. & Ganodermataceae & Polyporales & $\begin{array}{l}\text { core polyporoid } \\
\text { clade }\end{array}$ & $\begin{array}{c}\text { Wood (Ocotea foetens), Cubo de la } \\
\text { Galga (La Palma) }\end{array}$ & + & + & 6 & 6 & WRW \\
\hline 44708 & Phlebia radiata Fr. & Meruliaceae & Polyporales & phlebiod clade & $\begin{array}{l}\text { Wood (Ilex aquifolium), Robregordo } \\
\text { (Madrid) }\end{array}$ & + & + & 3 & 3 & WRW \\
\hline 44716 & $\begin{array}{l}\text { Phlebia rufa (Pers.) } \\
\text { M.P. Christ. }\end{array}$ & Meruliaceae & Polyporales & phlebiod clade & $\begin{array}{l}\text { Wood (Ocotea foetens), Cubo de la } \\
\text { Galga (La Palma) }\end{array}$ & + & + & 8 & 8 & WRW \\
\hline 44709 & $\begin{array}{l}\text { Polyporus arcularius (Batsch) } \\
\text { Fr. } \\
\end{array}$ & Polyporaceae & Polyporales & $\begin{array}{c}\text { core polyporoid } \\
\text { clade }\end{array}$ & $\begin{array}{c}\text { Wood (Prunus lusitánica), } \\
\text { Las Villuercas (Cáceres) }\end{array}$ & + & + & 6 & 7 & WRW \\
\hline 44704 & $\begin{array}{c}\text { Trametes pubescens } \\
\text { (Schumach.) Pilát }\end{array}$ & Polyporaceae & Polyporales & $\begin{array}{l}\text { core polyporoid } \\
\text { clade }\end{array}$ & $\begin{array}{c}\text { Wood (Laurus azorica), Pared Vieja } \\
\text { (La Palma) }\end{array}$ & + & + & 8 & 8 & WRW \\
\hline 44710 & $\begin{array}{l}\text { Trametes versicolor (L.) } \\
\text { Lloyd }\end{array}$ & Polyporaceae & Polyporales & $\begin{array}{l}\text { core polyporoid } \\
\text { clade }\end{array}$ & $\begin{array}{l}\text { Wood (Prunus lusitanica), } \\
\text { Las Villuercas (Cáceres) }\end{array}$ & + & + & 5 & 5 & WRW \\
\hline 44714 & $\begin{array}{l}\text { Trametes versicolor (L.) } \\
\text { Lloyd }\end{array}$ & Polyporaceae & Polyporales & $\begin{array}{l}\text { core polyporoid } \\
\text { clade }\end{array}$ & $\begin{array}{c}\text { Wood (Ocotea foetens), Cubo de la } \\
\text { Galga (La Palma) }\end{array}$ & + & + & 8 & 6 & WRW \\
\hline 44715 & $\begin{array}{l}\text { Trametes versicolor (L.) } \\
\text { Lloyd }\end{array}$ & Polyporaceae & Polyporales & $\begin{array}{l}\text { core polyporoid } \\
\text { clade }\end{array}$ & $\begin{array}{c}\text { Wood (Ocotea foetens), Cubo de la } \\
\text { Galga (La Palma) }\end{array}$ & + & + & 8 & 6 & WRW \\
\hline 44711 & $\begin{array}{l}\text { Trametes versicolor (L.) } \\
\text { Lloyd }\end{array}$ & Polyporaceae & Polyporales & $\begin{array}{l}\text { core polyporoid } \\
\text { clade }\end{array}$ & $\begin{array}{c}\text { Wood (Ocotea foetens), Pared Vieja } \\
\text { (La Palma) }\end{array}$ & + & + & 8 & 8 & WRW \\
\hline 44717 & $\begin{array}{l}\text { Steccherinum ochraceum } \\
\text { (Pers.) Gray }\end{array}$ & Steccherinaceae & Polyporales & $\begin{array}{c}\text { residual } \\
\text { polyporoid clade }\end{array}$ & $\begin{array}{l}\text { Wood (Alnus glutinosa), Las Batuecas } \\
\text { (Salamanca) }\end{array}$ & + & - & 10 & - & WRW \\
\hline 44703 & $\begin{array}{l}\text { Sidera lenis (P. Karst.) } \\
\text { Miettinen }\end{array}$ & Repetobasidiaceae & Hymenochaetales & $\begin{array}{l}\text { hymenochaetoid } \\
\text { clade }\end{array}$ & $\begin{array}{c}\text { Wood (Pinus radiata), Pared Vieja } \\
\text { (La Palma) }\end{array}$ & + & + & 6 & 8 & WRW \\
\hline 40210 & $\begin{array}{l}\text { Agrocybe pediades (Fr.) } \\
\text { Fayod } \\
\end{array}$ & Strophariaceae & Agaricales & agaricoid clade & $\begin{array}{c}\text { Humus (Grass), Cantalojas } \\
\text { (Guadalajara) }\end{array}$ & + & - & 14 & - & WRH \\
\hline 40215 & $\begin{array}{c}\text { Agrocybe praecox (Pers.) } \\
\text { Fayod }\end{array}$ & Strophariaceae & Agaricales & agaricoid clade & $\begin{array}{l}\text { Humus (Betula pendula), Cantalojas } \\
\text { (Guadalajara) }\end{array}$ & + & - & 12 & - & WRH \\
\hline 40153 & $\begin{array}{l}\text { Crucibulum laeve (Huds.) } \\
\text { Kambly }\end{array}$ & Nidulariaceae & Agaricales & agaricoid clade & $\begin{array}{c}\text { Humus (Fagus sylvatica), Selva de Oza } \\
\text { (Huesca) }\end{array}$ & + & - & 10 & - & WRH \\
\hline 44718 & Cyathus olla (Batsch) Pers. & Nidulariaceae & Agaricales & agaricoid clade & $\begin{array}{l}\text { Humus (Pinus halepensis), Alcalá de } \\
\text { Henares (Madrid) }\end{array}$ & + & - & 5 & - & WRH \\
\hline 40144 & $\begin{array}{l}\text { Cyathus striatus (Huds.) } \\
\text { Willd. } \\
\end{array}$ & Nidulariaceae & Agaricales & agaricoid clade & $\begin{array}{c}\text { Wood (Fagus sylvatica), Belagua } \\
\text { (Navarra) }\end{array}$ & + & - & 15 & - & WRW \\
\hline 44721 & $\begin{array}{l}\text { Gymnopilus junonius (Fr.) } \\
\text { P.D. Orton }\end{array}$ & Strophariaceae & Agaricales & agaricoid clade & $\begin{array}{c}\text { Wood (Pinus radiata), Pared Vieja } \\
\text { (La Palma) }\end{array}$ & + & - & 15 & - & WRW \\
\hline 40209 & $\begin{array}{l}\text { Gymnopus aquosus (Bull.) } \\
\text { Antonín \& Noordel. }\end{array}$ & Marasmiaceae & Agaricales & marasmioid clade & $\begin{array}{c}\text { Humus (Betula pendula), Cantalojas } \\
\text { (Guadalajara) }\end{array}$ & + & - & 15 & - & WRH \\
\hline 40138 & $\begin{array}{l}\text { Gymnopus confluens (Pers.) } \\
\text { Antonín, Halling \& Noordel. }\end{array}$ & Marasmiaceae & Agaricales & marasmioid clade & $\begin{array}{l}\text { Humus (Fagus sylvatica), Selva de Irati } \\
\text { (Navarra) }\end{array}$ & + & - & 15 & - & WRH \\
\hline 40214 & $\begin{array}{l}\text { Gymnopus dryophilus (Bull.) } \\
\text { Murrill } \\
\end{array}$ & Marasmiaceae & Agaricales & marasmioid clade & $\begin{array}{c}\text { Humus (Fagus sylvatica), Cantalojas } \\
\text { (Guadalajara) }\end{array}$ & + & - & 10 & - & WRH \\
\hline 40212 & $\begin{array}{l}\text { Gymnopus ocior (Pers.) } \\
\text { Antonín \& Noordel. }\end{array}$ & Marasmiaceae & Agaricales & marasmioid clade & $\begin{array}{c}\text { Humus (Betula pendula), Cantalojas } \\
\text { (Guadalajara) }\end{array}$ & + & - & 6 & - & WRH \\
\hline 40270 & Lepista nuda (Bull.) Cooke & Tricholomataceae & Agaricales & $\begin{array}{l}\text { tricholomatoid } \\
\text { clade }\end{array}$ & $\begin{array}{c}\text { Humus (Pinus halepensis), Alcalá de } \\
\text { Henares (Madrid) }\end{array}$ & + & - & 8 & - & WRH \\
\hline 40158 & Lycoperdon sp. & Agaricaceae & Agaricales & agaricoid clade & $\begin{array}{l}\text { Humus (Fagus sylvatica), Bosque de } \\
\text { Gamueta (Huesca) }\end{array}$ & + & - & 6 & - & WRH \\
\hline 44722 & Lycoperdon sp. & Agaricaceae & Agaricales & agaricoid clade & $\begin{array}{l}\text { Humus (Ocotea foetens), Cubo de la } \\
\text { Galga (La Palma) }\end{array}$ & + & - & 5 & - & WRH \\
\hline 44720 & $\begin{array}{l}\text { Macrocystidia cucumis (Pers.) } \\
\text { Joss. }\end{array}$ & Marasmiaceae & Agaricales & marasmioid clade & $\begin{array}{c}\text { Humus (Laurus azorica), Pared Vieja } \\
\text { (La Palma) }\end{array}$ & + & - & 8 & - & WRH \\
\hline 40150 & Mycena arcangeliana Bres. & Mycenaceae & Agaricales & $\begin{array}{c}\text { tricholomatoid } \\
\text { clade }\end{array}$ & $\begin{array}{c}\text { Humus (Fagus sylvatica), Bosque de } \\
\text { Gamueta (Huesca) }\end{array}$ & + & - & 8 & - & WRH \\
\hline 40321 & $\begin{array}{l}\text { Mycena leptocephala (Pers.) } \\
\text { Gillet }\end{array}$ & Mycenaceae & Agaricales & $\begin{array}{l}\text { tricholomatoid } \\
\text { clade }\end{array}$ & $\begin{array}{l}\text { Humus (Pinus halepensis), Alcalá de } \\
\text { Henares (Madrid) }\end{array}$ & + & - & 10 & - & WRH \\
\hline 40131 & $\begin{array}{l}\text { Mycena polygramma } \\
\text { f. pumila J.E. Lange }\end{array}$ & Mycenaceae & Agaricales & $\begin{array}{l}\text { tricholomatoid } \\
\text { clade }\end{array}$ & $\begin{array}{c}\text { Humus (Fagus sylvatica), Selva de Irati } \\
\text { (Navarra) }\end{array}$ & + & - & 8 & - & WRH \\
\hline 40185 & Mycena rosea Gramberg & Mycenaceae & Agaricales & $\begin{array}{l}\text { tricholomatoid } \\
\text { clade }\end{array}$ & $\begin{array}{l}\text { Humus (Castanea sativa), Las Batuecas } \\
\text { (Salamanca) }\end{array}$ & + & - & 9 & - & WRH \\
\hline 44719 & Mycena sp. & Mycenaceae & Agaricales & $\begin{array}{l}\text { tricholomatoid } \\
\text { clade }\end{array}$ & $\begin{array}{c}\text { Humus (Ocotea foetens), Los Tiles } \\
\text { (La Palma) }\end{array}$ & + & - & 15 & - & WRH \\
\hline 36488 & $\begin{array}{l}\text { Oudemansiella mucida } \\
\text { (Schrad.) Höhn }\end{array}$ & Physalacriaceae & Agaricales & marasmioid clade & $\begin{array}{c}\text { Wood (Fagus sylvatica), Cantalojas } \\
\text { (Guadalajara) }\end{array}$ & + & - & 12 & - & WRW \\
\hline 19073 & $\begin{array}{l}\text { Pholiota conissans (Fr.) } \\
\text { M.M. Moser }\end{array}$ & Strophariaceae & Agaricales & agaricoid clade & $\begin{array}{l}\text { Humus (Grass), Cabañeros } \\
\text { (Ciudad Real) }\end{array}$ & + & - & 5 & - & WRH \\
\hline 40177 & $\begin{array}{l}\text { Rhodocollybia butyracea } \\
\text { (Bull.) Lennox }\end{array}$ & Marasmiaceae & Agaricales & marasmioid clade & $\begin{array}{c}\text { Humus (Castanea sativa), Las Batuecas } \\
\text { (Salamanca) }\end{array}$ & + & - & 8 & - & WRH \\
\hline 40137 & $\begin{array}{l}\text { Xerula radicata (Relhan) } \\
\text { Dörfelt }\end{array}$ & Physalacriaceae & Agaricales & marasmioid clade & $\begin{array}{c}\text { Wood (Fagus sylvatica), Selva de Irati } \\
\text { (Navarra) }\end{array}$ & + & - & 14 & - & WRW \\
\hline
\end{tabular}

a $\quad \mathrm{WRW}=$ white-rot wood decolorization pattern. $\mathrm{WRH}=$ white-rot humus decolorization pattern. 


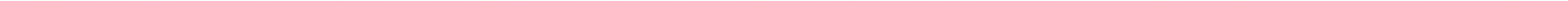


S + Catalase
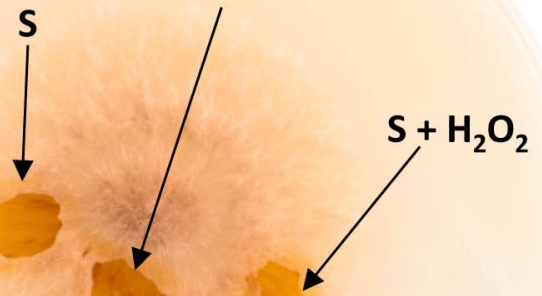

S + catalase

\section{$\mathrm{S}+\mathrm{H}_{2} \mathrm{O}_{2}$}

S 
A

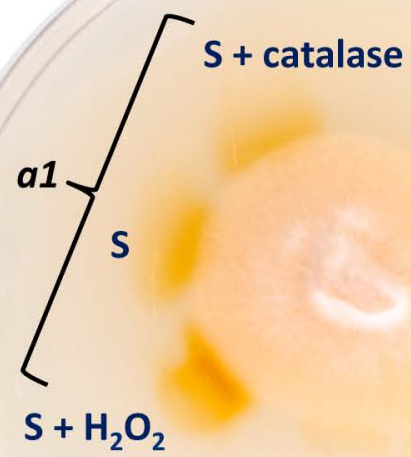

S + catalase

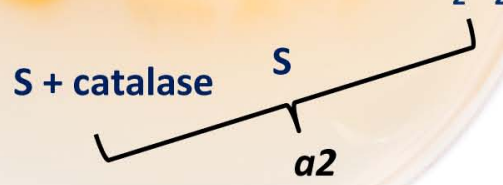

B

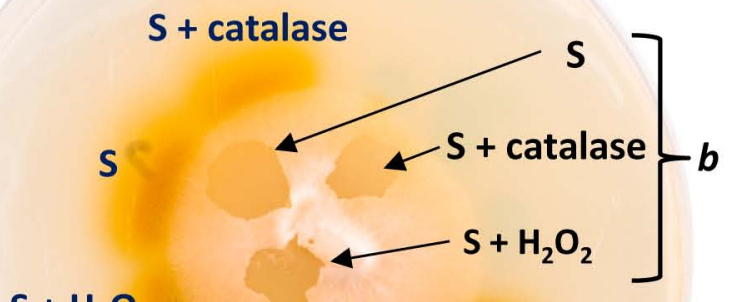

$\mathrm{S}+\mathrm{H}_{2} \mathrm{O}_{2}$

$$
\mathrm{S}+\text { catalase } \quad \mathrm{S}+\mathrm{H}_{2} \mathrm{O}_{2}
$$


B
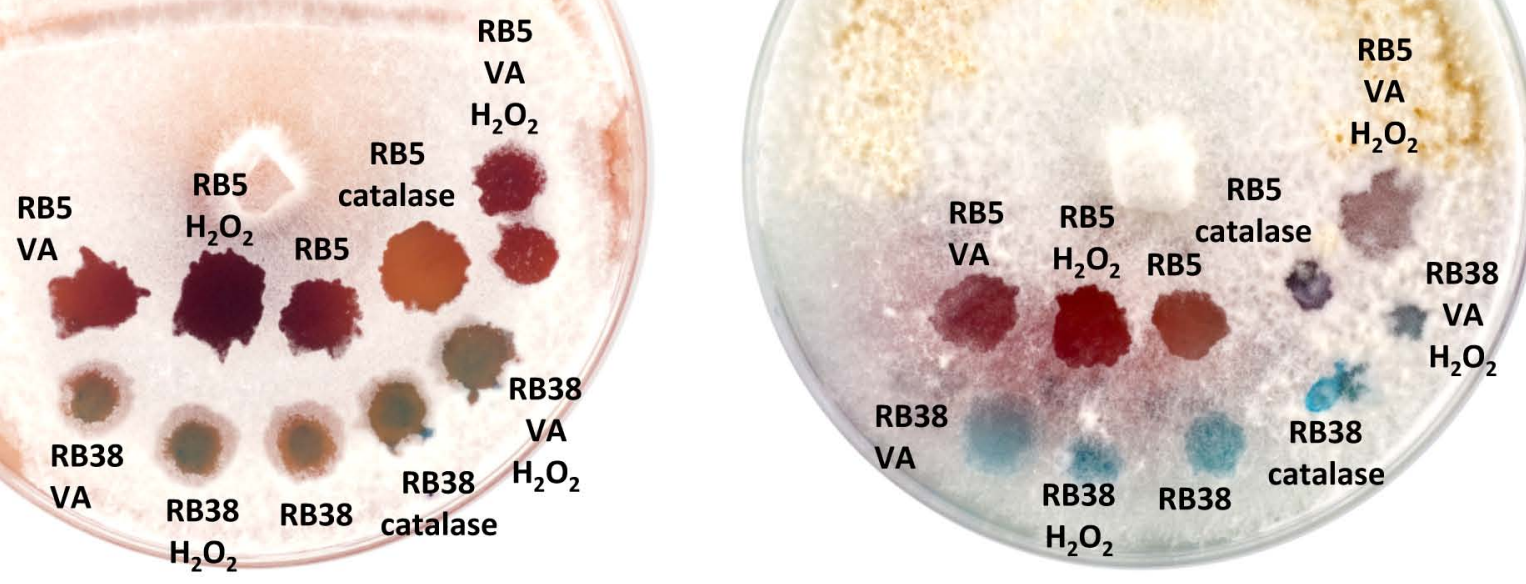
A

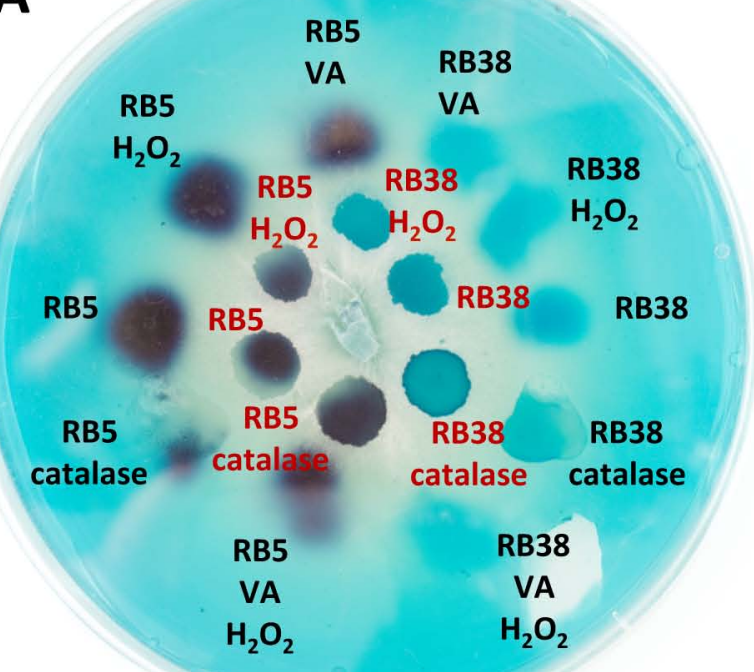

B

$\mathrm{H}_{2} \mathrm{O}_{2}$

RB5

VA RB38

VA $\begin{array}{lll}\text { RB5 } & \text { RB38 } \\ \text { RB38 }\end{array}$ $\begin{array}{lll}\mathrm{H}_{2} \mathrm{O}_{2} & \mathrm{H}_{2} \mathrm{O}_{2} & \mathrm{H}_{2} \mathrm{O}_{2}\end{array}$

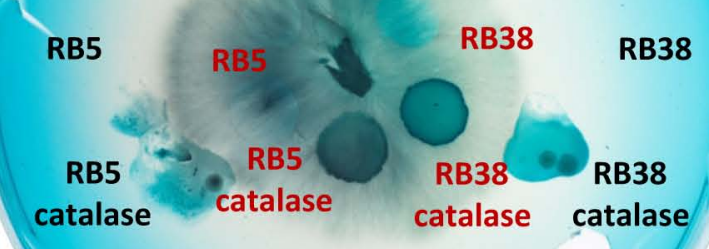

RB5

VA

$\mathrm{H}_{2} \mathrm{O}_{2}$
RB38

VA

$\mathrm{H}_{2} \mathrm{O}_{2}$ 